\title{
MEKANISME DAN PROSEDUR PEMBUKAAN RAHASIA BANK ${ }^{*}$
}

\author{
Bambang Catur $\mathrm{SP}^{1}$ \\ Permalink: https://www.academia.edu/9964222
}

\begin{abstract}
Mechanisms and procedures at the Opening of Bank Secrecy. The bank secrecy is the right of customer, which must be maintained by the bank. Bank Secrecy is all things related to the storage of information about customers and their savings. However, there are some provisions that allow for the bank to open a secret bank customers, with the for the benefit of the State and society, the purpose of taxation, national trade interests, the interests of the criminal and civil justice, the importance of banking activities, and all set in legislation.
\end{abstract}

\section{Keywords: Bank, Bank Secrecy, Opening Procedures}

\begin{abstract}
Abstrak: Mekanisme dan Prosedur Pembukaan Rahasia Bank. Pada dasarnya rahasia bank merupakan hak nasabah yang harus dijaga oleh pihak bank. Rahasia Bank adalah segala sesuatu yang berhubungan dengan keterangan mengenai nasabah penyimpanan dan simpanannya. Akan tetapi ada beberapa ketentuan yang membolehkan bagi pihak bank untuk membuka rahasia bank nasabahnya, dengan ketentuan untuk kepentingan Negara dan masyarakat luas, untuk kepentingan perpajakan, untuk kepentingan piutang negara, untuk kepentingan peradilan pidana dan perdata, untuk kepentingan kegiatan perbankan, dan semuanya diatur dalam peraturan perundangundangan.
\end{abstract}

Kata Kunci: Bank, Rahasia Bank, Prosedur Pembukaan

Diterima tanggal naskah diterima: 22 Maret 2014, direvisi: 07 April 2014, disetujui untuk terbit: 10 Juni 2014.

${ }^{1}$ Fakultas Syariah dan Hukum UIN Jakarta. Jl. Ir. H. Juanda No. 95 Ciputat Jakarta. E-mail: bambang.catur@yahoo.com. 


\section{Pendahuluan}

Perbankan, khususnya bank umum merupakan inti dari sistem keuangan negara. Bank merupakan lembaga keuangan yang menjadi tempat pengusaha, badan-badan pemerintah dan swasta, maupun perorangan menyimpan dana-dananya. Melalui kegiatan perkreditan dan berbagai jasa diberikan, bank melayani kebutuhan pembiayaan serta melancarkan mekanisme sistem pembayaran bagi semua sektor perkembangan.

Menurut ketentuan Undang-Undang Nomor 7 Tahun 1992 tentang Perbankan maupun Undang-undang perubahannya yaitu Undang-undang Nomor 10 Tahun 1998, jasa perbankan dapat diberikan oleh bank harus sesuai dengan jenis banknya. Berarti pelayanan yang dapat diberikan oleh bank dipengaruhi oleh jenis bank yang bersangkutan, mengingat ada ketentuan usaha perbankan tertentu yang hanya dapat diberikan oleh Bank Umum tetapi tidak boleh diberikan oleh Bank Perkreditan Rakyat (BPR), misalnya BPR dilarang menerima simpanan berupa giro. Dengan demikian, maka jenis bank menentukan usaha perbankan yang dapat diberikan kepada masyarakat.

Dalam ketentuan Undang-Undang Nomor 7 Tahun 1992 tentang Perbankan khususnya pada Bab II tentang Jenis dan Usaha Bank pada pasal 6 dan 7 diatur mengenai ketentuan usaha perbankan yang dapat dilakukan oleh Bank Umum. Usaha perbankan yang dilakukan oleh Bank Umum diantaranya: a). Penghimpun dana dari masyarakat; b). Pemberian kredit; c). Penerbitan surat pengakuan hutang; d). Jual beli surat berharga, atau menjamin atas risiko sendiri maupun untuk kepentingan dan atas perintah nasabahnya; e). Pemindahan uang; f). Penempatan dana pada bank lainnya, meminjam dana dari atau meminjamkan dana kepada bank lainnya; g). Penempatan dana pada bank lainnya, meminjam dana dari atau meminjamkan dana kepada bank lainnya; h). Penerimaan pembayaran tagihan surat berharga; i). Penyimpanan barang dan surat berharga; j). Menerima penitipan untuk kepentingan pihak lain; k). Penempatan dana dari nasabah kepada nasabah lainnya dalam bentuk surat berharga yang tidak tercatat di bursa efek; 1). Usaha anjak piutang, kartu kredit, dan kegiatan wali amanat; m). membiayaan dengan prinsip Syan'ah; n). Melakukan kegiatan dalam valuta asing; o). Melakukan kegiatan penyertaan modal sementara untuk mengatasi akibat kegagalan kredit, dengan syarat dengan menarik kembali penyertaannya dengan memenuhi ketentuan yang ditetapkan oleh Bank Indonesia; q). Pengurusan dan pendirian dana pensiun.

\section{Pengertian Bank}

Beberapa pengertian tentang bank telah dikemukakan baik oleh para ahli maupun menurut undang-undang, di mana dari beberapa pengertian itu terdapat satu pengertian yang sama khususnya yang berkaitan dengan adanya suatu badan yang usahanya terutama memberikan kredit, baik dengan modalnya sendiri maupun dengan modal pihak lain. ${ }^{2}$

Menurut undang-undang No. 10 Tahun 1998 tentang Perbankan,

${ }^{2}$ Bambang Sunggonc, Pengantar Hukum Perbankan, (Bandung: Mandar Maju, 1995), 
dalam pasal 1 angka 2 dinyatakan: "Bank adalah badan usaha yang menghimpun dana dari masyarakat dalam bentuk simpanan dan menyalurkannya kepada masyarakat dalam bentuk kredit dan/atau bentukbentuk lainnya dalam rangka meningkatkan taraf hidup rakyat banyak."

Di samping itu, ada beberapa sarjana yang memberikan pengertian mengenai bank antara lain sebagai berikut:

Pertama, Prof. G.M. Verryn Stuart dalam bukunya Bank Politik: mengatakan bahwa: "Bank adalah suatu badan yang bertujuan untuk memuaskan kebutuhan kredit, baik dengan alat-alat pembayarannya sendiri atau dengan uang yang diperolehnya dari orang lain, maupun dengan jalan memperedarkan alat-alat penukar baru berupa uang giral. ${ }^{34}$

Kedua, A. Abdurrachman dalam bukunya Ensiklopedia Ekonomi Keuangan dan Perdagangan menjelaskan bahwa: "Bank adalah suatu jenis lembaga keuangan yang melaksanakan berbagai macam jasa, seperti memberikan pinjaman, mengedarkan mata uang, pengawasan terhadap mata uang, bertindak sebagai tempat penyimpanan benda-benda berharga, membiayai usaha perusahaan-perusahaan dan lain-lain."

Ketiga, Muchdarsyah Sinungan menjelaskan bahwa: "Bank adalah suatu lembaga keuangan yang usaha pokoknya memberikan kredit dan jasa-jasa dalam lalu lintas pembayaran dan peredaran uang."

Keempat, Fockema Andreae dalam bukunya Kamus Istilah Hukum mengatakan bahwa: "Bank ialah suatu lembaga atau orang pribadi yang menjalankan perusahaan dalam menerima dan memberikan uang dari dan kepada perusahaan dalam menerima dan memberikan uang dari dan kepada pihak ketiga. Berhubung dengan adanya cek yang hanya dapat diberikan kepada bankir sebagai tertarik, maka bank dalam arti luas adalah orang atau lembaga yang dalam pekerjaannya secara teratur menyediakan uang untuk pihak ketiga."

Kelima, O.P. Simorangkir dalam bukunya Seluk Beluk Bank Komersial mengatakan bahwa: "Bank merupakan salah satu badan usaha lembaga keuangan yang bertujuan memberikan kredit dan jasa-jasa. Adapun pemberian kredit itu dilakukan baik dengan modal sendiri atau dengan dana-dana yang dipercayakan oleh pihak ketiga maupun dengan jalan memperedarkan alat-alat pembayaran berupa uang giral."

Dari beberapa pengertian tersebut di atas jelas bahwa usaha bank pada dasarnya merupakan suatu usaha simpan-pinjam demi dan untuk kepentingan

${ }^{3}$ Undang-Undang No. 10 Tahun 1998, tentang Perbankan, h. 9

${ }^{4}$ G.M. Verryn Stuart, "Bank Politik", dalam Thomas Suyatno. et. al., Kelembagaan Perbankan, (Jakarta: Gramedia, 1992), h. 1

A. Abdurrachman, Ensiklopedia Ekonomi Keuangan dan Perbanakan, dalam Thomas Suyamo, et al., Kelembagaan Perbankan, h.1

${ }_{7}^{6}$ Muchdarsyah Sinungan, Manajemen Dana Bank, (Jakarta: Bumi Aksara, 2000), h. 3

7 Fockema Andreae, "Kamus lstilah Hukum", dalam. H. Budi Untung, Kredit Perbankan di Indonesia, (Yogjakarta: Andi Yogjakarta, 2000), h. 13

${ }^{8}$ O.P. Simorangkir, Seluk Beluk Bank Komersial, Cetakan I, (Jakarta: Perbanas, 1998), h. 18 
pihak ketiga dan badan usahanya harus berbentuk badan hukum.

Dari pengertian di atas menjadi jelas bahwa usaha bank haruslah didirikan dalam bentuk badan hukum atau tidak boleh berbentuk usaha perseorangan. Penegasan seperti itu dapat dilihat dalam ketentuan pasal 21 Undang-Undang No. 10 Tahun 1998 yang menentukan bentuk hukum bank, yaitu: Perseroan Terbatas, Koperasi, atau Perusahaan Daerah.

Dengan demikian dari beberapa pengertian tersebut di atas, dapatlah ditarik suatu kesimpulan bahwa tugas pokok dari bank adalah memberikan kredit kepada masyarakat secara langsung, kecuali Bank Indonesia.

\section{Asas Perbankan di Indonesia}

Peraturan perbankan yang terbaru yaitu Undang-Undang No. 10 Tahun 1998 tentang Perbankan menyatakan adanya asas perbankan diatur dalam Bab II pasal 2. Dengan diaturnya dalam Undang-Undang No. 10 Tahun 1998, maka menjadi jelas apa landasan perbankan, bagaimana kegiatannya dan ke mana arahnya.

Mengenai asasnya ketentuan pasal 2 Undang-Undang No. 10 Tahun 1998, menyebutkan bahwa: "Perbankan Indonesia dalam melakukan usahanya berasaskan demokrasi ekonomi dengan menggunakan prinsip-prinsip kehatihatian."

Dalam Undang-Undang No. 10 Tahun 1998 tentang Perbankan ini tidak memberikan penjelasan tentang prinsip kehati-hatian, padahal kejelasan prinsip ini untuk mengetahui sejauhmana batas kehati-hatian perbankan agar antara kesengajaan dengan kealpaan mempunyai batas jelas dan tegas.

\section{Tujuan Perbankan}

Dalam Undang-Undang No. 10 Tahun 1998 tentang Perbankan, tujuan perbankan diatur dalam Bab II pasal 4. Mengenai tujuan perbankan ketentuan pasal 4 Undang-Undang No. 10 tahun 1998 menyebutkan bahwa: "Perbankan Indonesia bertujuan menunjang pelaksanaan pembangunan nasional dalam rangka meningkatkan pemerataan, pertumbuhan ekonomi, dan stabilitas nasional ke arah peningkatan kesejahteraan rakyat banyak." ${ }^{\prime 0}$

Ketentuan pasal 4 di atas terlihat bahwa bank tidak cukup hanya menjalankan kegiatannya saja, yaitu menghimpun dan menyalurkan dana masyarakat, tetapi kegiatan tersebut mempunyai tujuan yang jelas demi kepentingan pembangunan nasional merupakan sasaran perbankan dalam melakukan kegiatan sebagaimana tujuan tersebut di atas. Meningkatkan pemerataan, meningkatkan pertumbuhan ekonomi, dan meningkatkan stabilitas nasional.

\section{Fungsi Perbankan di Indonesia}

Fungsi bank ini diatur dalam ketentuan pasal 3 Undang-Undang No.10 Tahun 1998 tentang Perbankan menyebutkan bahwa: "Fungsi utama

\footnotetext{
${ }^{9}$ Undang- Undang No.10 Tahun 1998 tentang Perbankan, h. 69

${ }^{10}$ Undang- Undang No.10 Tahun 1998 tentang Perbankan, h. 70
} 
perbankan Indonesia adalah sebagai penghimpun dan penyalur dana masyarakat." ${ }^{\prime 1}$

Bank merupakan alat pemerintah di bawah koordinasi Bank Indonesia sebagai Bank Sentral, diberi fungsi sebagai berikut:

Pertama, Alat penyedot dana yang ada di masyarakat. Sasaran penyedotan dana adalah dana yang berlebihan di dalam masyarakat, atau dana yang sementara belum digunakan oleh pemiliknya. Adapun contohnya adalah: a). menjual deposito berjangka; b). menerima simpanan berjangka berupa rekening koran, tabanas, taska, dan sebagainya.

Kedua, Menyalurkan dana yang telah terhimpun itu kepada masyarakat, dengan jalan memberikan jaminan (garansi bank) dan memberikan pinjaman. ${ }^{12}$

Selanjutnya secara spesifik fungsi bank itu dapat dikelompokkan menjadi 3 yaitu : ${ }^{13}$

Pertama, Agent of Trust. Dasar utama kegiatan perbankan adalah trust atau kepercayaan, baik dalam hal penghimpun dana maupun penyalur dana. Masyarakat akan mau menitipkan dananya di bank apabila dilandasi oleh unsur kepercayaan. Masyarakat percaya bahwa uangnya tidak akan disalahgunakan oleh bank, uangnya akan dikelola dengan baik, bank tidak akan bangkrut, dan juga percaya bahwa pada saat yang telah dijanjikan masyarakat dapat menarik lagi simpanan dananya di bank.

Kedua, Agent of Development. Sektor dalam kegiatan perekonomian masyarakat yaitu sektor moneter dan sektor riil, tidak dapat dipisahkan. Sektor riil tidak dapat bekerja dengan baik apabila sektor moneter tidak bekerja dengan baik. Tugas bank adalah sebagai penghimpun dan penyalur dana sangat diperlukan untuk kelancaran kegiatan perekonomian di sektor riil. Kegiatan bank tersebut memungkinkan masyarakat melakukan investasi, distribusi, dan juga konsumsi barang dan jasa mengingat semua kegiatan itu berkaitan dengan penggunaan uang. Kelancaran kegiatan tersebut tidak lain adalah kegiatan pembangunan perekonomian masyarakat.

Ketiga, Agent of Services. Di samping melakukan penghimpun dan penyalur dana, bank juga memberikan penawaran jasa-jasa perbankan yang lain kepada masyarakat. Jasa-jasa yang ditawarkan ini erat kaitan dengan kegiatan perekonomian masyarakat secara umum. Jasa-jasa bank ini antara lain dapat berupa jasa pengiriman uang, jasa penitipan barang berharga, jasa pemberian jaminan bank, dan jasa penyelesaian tagihan.

Di samping itu, ada beberapa faktor yang menyebabkan bank menjadi sangat penting dalam mendorong pembangunan bangsa, yaitu: ${ }^{14}$ a). Pengumpul dana dari masyarakat yang kelebihan dana dan penyalur kredit kepada

\footnotetext{
${ }^{11}$ Undang- Undang No.10 Tahun 1998 tentang Perbankan, h. 70

${ }_{12}$ Achmad Anwari, Rekening Koran Giro, (Jakarta: Balai Aksara, 1991), h. 16

${ }^{13}$ Y. Sri Susilo dan Sigit Triandaru, Bank \& Lembaga Keuangan Lain, (Jakarta: Salemba Empat, 2000), h. 6

${ }^{14}$ H. Malayu SP. Hasibuan, Dasar-Dasar Perbankan, (Jakarta: Bumi Aksara, 2001), h. 
masyarakat yang membutuhkan dana; b). Tempat menabung yang efektif dan produktif bagi masyarakat; c). Pelaksana dan memperlancar lalu lintas pembayaran dengan aman, praktis, dan ekonomis; d). Penjamin penyelesaian perdagangan dengan menerbitkan L / C; dan e). Penjamin penyelesaian proyek dengan menerbitkan bank garansi.

\section{Jenis Perbankan di Indonesia}

Menurut ketentuan pasal 1 angka 5 dan 4 Undang-Undang No. 10 Tahun 1998 tentang Perbankan tersebut, bahwa bank dapat dibedakan berdasarkan jenisnya, yaitu:

Pertama, Bank Umum adalah bank yang melaksanakan kegiatan usaha secara konvensional dan/atau berdasarkan Prinsip Syariah yang dalam kegiatannya memberikan jasa dalam lalu lintas pembayaran.

Kedua, Bank Perkreditan Rakyat adalah bank yang melaksanakan kegiatan usaha secara konvensional atau berdasarkan Prinsip Syariah yang dalam kegiatannya tidak memberikan jasa dalam lalu lintas pembayaran. ${ }^{15}$

Pengertian dari kedua jenis bank di atas tercantum pada pasal 1 angka 3 dan 4 Undang-Undang No. 10 Tahun 1998, yaitu: Bank Umum adalah bank yang dapat memberikan jasa dalam lalu lintas pembayaran. Sedangkan Bank Perkreditan Rakyat adalah bank yang menerima simpanan hanya dalam bentuk deposito berjangka, tabungan dan atau bentuk lainnya yang dipersamakan dengan itu.

\section{Rahasia Bank}

Tinjauan teori tentang rahasia bank, menunjukkan ada dua pendapat. Yang pertama teori rahasia bersifat mutlak, yaitu bahwa bank berkewajiban menyimpan rahasia nasabah yang diketahui oleh bank karena kegiatan usahanya dalam keadaan apapun, biasa atau dalam keadaan luar biasa. Teori yang kedua adalah rahasia bank bersifat nisbi, yaitu: bahwa bank diperbolehkan membuka rahasia nasabahnya, bila untuk suatu kepentingan mendesak, misalnya demi kepentingan negara. ${ }^{16}$

Mengenai rahasia bank ini ketentuannya diatur dalam Pasal 28 Undang-Undang No. 10 tahun 1998 tentang Perbankan yang menyebutkan bahwa: "Rahasia Bank adalah segala sesuatu yang berhubungan dengan keterangan mengenai nasabah penyimpanan dan simpanannya."17

Sejalan dengan pengertian di atas, pasal 40 ayat 1 Undang-Undang No. 10 Tahun 1998 menegaskan bahwa bank wajib merahasiakan keterangan mengenai nasabah penyimpan dan simpanannya, kecuali dalam hal sebagaimana dimaksud dalam pasal 41, 41A, 42, 43, 44 dan 44A. Ini berarti bank dilarang memberikan keterangan yang tercatat pada bank tentang keadaan keuangan dan hal-hal lain dari nasabahnya, yang wajib dirahasiakan oleh bank menurut kelaziman dunia perbankan. Di sinilah yang dilarang oleh undang-

\footnotetext{
${ }^{15}$ Undang-undang No. 10 Tahun 1998 tentang Perbankan, h. 9

${ }_{17}^{16}$ Muhammad Djumhana, Op. cit., h. 164

${ }^{17}$ Undang-undang No. 10 Tahun 1998 tentang Perbankan, h. 12
} 
undang, bank memberi informasi mengenai keadaan keuangan nasabah.

Mekanisme dan prosedur permintaan untuk pembukaan rahasia bank, yaitu: 1). Pemohonan ditujukan kepada Pimpinan Bank Indonesia Up. Urusan Hukum Bank Indonesia; 2). Atas permintaan ini Pimpinan Bank Indonesia membahasnya dan kemudian memberikan keputusannya apakah memberikan atau menolaknya; 3). Apabila permintaan tersebut tidak memenuhi persyaratan dilakukan penolakan begitu juga sebaliknya apablia telah memenuhi persyaratan maka diijinkan pembukaan rahasia bank tersebut. ${ }^{18}$

Penolakan oleh Bank Indonesia selambat-lambatnya 14 (empat belas) hari setelah Surat permintaan diterima (pasal 8 ayat 3 Surat Keputusan Direksi Bank Indonesia 31/82/KEP/DIR tentang Persyaratan dan Tata, Cara Pemberian Ijin atau Perintah membuka rahasia bank. ${ }^{19}$

\section{Pembukaan Rahasia Bank Untuk Kepentingan Perpajakan}

Ketentuan mengenai pembukaan rahasia bank untuk kepentingan perpajakan ini diatur dalam pasal 41 Undang-undang Perbankan 1998 yang menyatakan bahwa: "Untuk kepentingan perpajakan, Pimpinan Bank Indonesia atas perintah Menteri Keuangan berwenang mengeluarkan perintah tertulis kepada bank agar memberikan keterangan dan memperlihatkan buktibukti tertulis serta Surat-Surat mengenai keadaan keuangan nasabah penyimpan tertentu kepada pejabat pajak." ${ }^{20}$

Dalam pembukaan rahasia bank karena untuk keperluan pemeriksaan dan penyidikan perpajakan, maka pembukaannya harus ada permintaan tertulis dari Menteri Keuangan. Adapun mengenai keperluan untuk menjalankan ketentuan peraturan perundang-undangan perpajakan lainnya maka tidak diperlukan permintaan. Hal demikian didasarkan kepada ketentuan pasal 35 ayat 1 dan 2 berikut penjelasannya dari Undang-Undang No. 9 Tahun 1994, yaitu bahwa untuk kepentingan menjalankan peraturan perundang-undangan pajak, pihak pajak langsung dapat meminta keterangan atau bukti dari bank mengenai keadaan keuangan nasabahnya sepanjang mengenai perpajakannya. ${ }^{21}$

\section{Pembukaan Rahasia Bank Untuk Kepentingan Penyelesaian Piutang Negara}

Ketentuan untuk pembukaan rahasia bank, karena kepentingan penyelesaian piutang negara merupaknn ketentuan yang baru. Pasal yang mengaturnya yaitu: pasal 41 A ayat 1, 2 dan 3 Undang-Undang Perbankan tahun 1998 yang berbunyi sebagai berikut:

Pertama, untuk penyelesaian piutang bank yang sudah diserahkan kepada Badan Urusan Piutang dan Lelang Negara/Panitia Urusan Piutang Negara, Pimpinan Bank Indonesia memberikan ijin kepada pejabat Badan Urusan Piutang dan Lelang Negara/Panitia Urusan Piutang Negara untuk

${ }^{18}$ Muhammad Djumhana, Hukum Perbankan di Indonesia, (Bandung: PT. Citra Aditya Bakti, 2000), h. 168

\footnotetext{
${ }^{19}$ Muhammad Djumhana, Hukum Perbankan di Indonesia, h.168

${ }^{20}$ Undang-undang No. 10 tahun 1998 tentang Perbankan, h. 25

${ }^{21}$ Muhammad Djumhana, Hukum Perbankan di Indonesia, h. 169
} 
memperoleh keterangan dari bank mengenai simpanan nasabah dari debitur.

Kedua, ijin sebagaimana dimaksud dalam ayat 1 diberikan secara tertulis atas permintaan tertulis Kepala Badan Urusan Piutang dan Lelang Negara/Ketua Panitia Urusan Piutang Negara;

Ketiga, permintaan sebagaimana dimaksud dalam ayat 2 harus menyebutkan nama dan jabatan pejabat Badan Urusan Piutang dan Lelang Negara/Panitia Urusan Piutang Negara, nama nasabah debitur yang bersangkutan, dan alasan diperlukan keterangan. ${ }^{22}$

Dengan demikian dari ketentuan di atas dapat ditarik suatu kesimpulan bahwa ijin untuk pembukaan rahasia bank dalam rangka penyelesaian piutang negara tersebut dapat diperoleh apabila dilakukan permohonan secara tertulis oleh Kepala Badan Urusan Piutang dan Lelang Negara/Ketua Panitia Urusan Piutang Negara. Permintaan tersebut harus menyebutkan nama dan jabatan pejabat Badan Urusan Piutang dan Lelang bersangkutan, dan alasan diperlukannya keterangan.

\section{Pembukaan Rahasia Bank Untuk Kepentingan Peradilan Pidana}

Menurut ketentuan pasal 42 ayat 1, 2, dan 3 Undang-Undang Perbankan Tahun 1998 menyatakan sebagai berikut:

Pertama, untuk kepentingan peradilan dalam perkara pidana, Pimpinan Bank Indonesia dapat memberikan ijin kepada Polisi, Jaksa, atau Hakim untuk memperoleh keterangan dari bank mengenai simpanan tersangka atau terdakwa pada bank;

Kedua, ijin sebagaimana dimaksud dalam ayat 1 diberikan secara tertulis atas permintaan tertulis dari Kepala Kepolisian. Republik Indonesia, Jaksa Agung atau Ketua Mahkamah Agung;

Ketiga, permintaan sebagaimana dimaksud dalam ayat 2 harus menyebutkan nama dan jabatan Polisi, Jaksa atau Hakim, nama tersangka atau terdakwa, alasan diperlukannya keterangan dan hubungan perkara pidana yang bersangkutan dengan perkara pidana yang diperlukan. ${ }^{23}$

Di dalam Pasal 3 Ayat (1) tentang Pembukaan Rahasia Bank untuk kepentingan peradilan dalam perkara pidana wajib dilakukan setelah terlebih dahulu memperoleh perintah atau izin tertulis dari pimpinan Bank Indonesia.

Di dalam Pasal 6 mengatur tentang pembukaan rahasia perbankan di dalam kepentingan peradilan dalam perkara pidana, di mana pimpinan BI dapat memberikan izin tertulis kepada polisi, jaksa atau hakim untuk memperoleh keterangan dari bank mengenai simpanan tersangka atau terdakwa pada bank (Ayat (1)), setelah ada permintaan tertulis dari Kepala Kepolisian Republik Indonesia (Ayat (2)), hal mana ketentuan tersebut juga berlaku di dalam perkara pidana yang diproses di luar peradilan umum[11] (Ayat (3)) di mana permintaan tertulis tersebut harus menyebutkan: a. Nama dan jabatan polisi, jaksa atau hakim; b. Nama tersangka atau terdakwa; c. Nama kantor bank tempat tersangka atau terdakwa mempunyai simpanan; d. Keterangan

\footnotetext{
${ }^{22}$ Undang-undang No. 10 Tahun 1998 tentang Perbankan, h. 25 - 26

${ }^{23}$ Undang-undang No. 10 Tahun 1998 tentang Perbankan, h. 26
} 
yang diminta; e. Alasan diperlukannya keterangan; dan f. Hubungan perkara pidana yang bersangkutan dengan keterangan yang diperlukan.

Bahwa kemudian hari lebih lanjut diatur di dalam Pasal 9, bahwa permintaan tertulis tersebut harus ditandatangani dengan membubuhkan tanda tangan basah oleh Jaksa Agung Republik Indonesia, Kepolisian Republik Indonesia atau Ketua Mahkamah Agung Republik Indonesia, yang ditujukan kepada: Gubernur Bank Indonesia Up. Direktorat Hukum Bank Indonesia.

Selambat-lambatnya 14 (empat belas) hari setelah surat permintaan untuk kepentingan peradilan dalam perkara pidana diterima secara lengkap oleh Direktorat Hukum BI, Gubernur BI memberikan perintah atau izin tertulis membuka rahasia bank, kecuali untuk perkara pidana korupsi, perintah atau izin diberikan dalam waktu 3 (tiga) hari. Demikian juga terhadap surat permintaan yang tidak memenuhi persyaratan, Gubernur BI secara tertulis dapat menolak untuk memberikan perintah atau izin tertulis membuka rahasia bank, selambat-lambatnya 14 (empat belas) hari setelah surat permintaan diterima untuk kepentingan perkara pidana dan 3 (tiga) hari setelah permintaan diterima yang berkaitan dengan tindak pidana korupsi. (Pasal 10 Ayat (3) dan (4)).

Perintah atau izin tertulis membuka rahasia bank, maupun penolakannya, dapat dilakukan oleh deputi gubernur senior atau salah satu deputi gubernur (Pasal 11 Ayat (1) dan (2)).

Mengenai perintah atau izin tertulis yang telah dikeluarkan oleh Gubernur BI, yang juga dapat dikeluarkan oleh Deputi Senior Gubernur BI atau salah satu deputi gubernur, pihak bank wajib melaksanakan dengan memberikan keterangan baik lisan maupun tertulis, memperlihatkan buktibukti tertulis, surat-surat dan hasil cetak data elektronis, tentang keadaan keuangan nasabah penyimpan, yang disebutkan dalam perintah atau izin tertulis tersebut.

Di dalam penjelasan Pasal 7 Ayat (2), bahwa termasuk dalam pengertian keterangan secara tertulis adalah pemberian fotokopi bukti-bukti tertulis, fotokopi surat-surat dan hasil cetak data elektronis yang telah dinyatakan/diberi tanda sesuai dengan aslinya (certified) oleh pejabat yang berwenang pada bank. Pemberian keterangan secara tertulis tersebut perlu dilakukan sedemikian rupa agar tidak mengganggu dan menghilangkan dokumen yang menurut ketentuan seharusnya tetap diadministrasikan oleh bank yang bersangkutan. Kata memperlihatkan dalam ketentuan ini tidak berarti bahwa pembawa perintah atau izin tertulis dari Bank Indonesia dapat melakukan pemeriksaan bank.

Juga diatur secara khusus di Pasal 8, bahwa bank dilarang memberikan keterangan tentang keadaan keuangan nasabah penyimpan selain yang disebutkan dalam perintah atau izin tertulis dari Bank Indonesia.

Sebagai tambahan dan cukup penting untuk diketahui, bahwa terhadap pemblokiran atau penyitaan simpanan atas nama nasabah penyimpan yang telah dinyatakan sebagai tersangka atau terdakwa dapat dilakukan tanpa 
memerlukan izin $\mathrm{BI}[12]$, kecuali untuk memperoleh keterangan mengenai nasabah penyimpan dan simpanan nasabah yang diblokir atau disita pada bank, berlaku ketentuan sebagaimana diatur dalam peraturan BI ini (Pasal 12 Ayat (1) dan (2)).

Dengan demikian ketentuan di atas nampak jelaslah bahwa untuk kepentingan peradilan dalam perkara pidana, Pimpinan Bank Indonesia dapat memberikan ijin kepada Polisi, Jaksa atau Hakim untuk memperoleh keterangan dari bank tentang keadaan keuangan tersangka/terdakwa pada bank.

\section{Pembukaan Rahasia Bank Untuk Kepentingan Peradilan Dalam Perkara Perdata}

Pengecualian yang berlaku dalam perkara perdata, informasi yang dapat diberikan bank hanya terbatas pada sengketa bank dengan nasabahnya. Hal ini sesuai dengan pasal 43 Undang-Undang Perbankan 1992, bahwa direksi bank yang bersangkutan dapat menginformasikan kepada pengadilan tentang keadaan keuangan nasabah yang menjadi lawannya dan memberikan keterangan lain yang relevan dengan perkara tersebut.

Dengan adanya pengecualian tersebut, maka direksi bank tidak perlu menunggu ijin tertulis dari Menteri Keuangan, sebab dalam perkara perdata keuangan nasabah selain dipergunakan untuk mengungkapkan kebenaran fakta di persidangan, juga menyangkut kepentingan bank itu sendiri dalam melawan nasabahnya.

\section{Pembukaan Rahasia Bank Untuk Kepentingan Kegiatan Perbankan}

Dalam rangka tukar menukar informasi antar bank, sistemnya sama dengan di atas, bank tidak perlu menunggu perintah dari menteri keuangan. Direksi bank dapat memberitahukan keadaan keuangan nasabahnya kepada bank lain. Pengecualian ini dimaksudkan sebagai sarana untuk menunjang kegiatan usaha bank itu sendiri. Peraturan pelaksanaan dan ketentuan mengenai tukar menukar informasi mencakup pengaturan mengenai tata cara penyampaian dan permintaan informasi serta bentuk dan jenis informasi tertentu yang dapat dipertukarkan, seperti indikator secara garis besar kredit yang diterima nasabah, agunan, dan masuk tidaknya debitur yang bersangkutan dalam daftar kredit macet. Peraturan yang berlaku saat ini yaitu Surat Keputusan Direksi Bank Indonesia No. 27/120/KEP/DIR tentang Tata Cara Tukar Menukar Informasi Antar Bank, Tanggal 25 Januari 1995. ${ }^{24}$

Bagaimana tata cara untuk menerobos rahasia bank dijabarkan lebih lanjut dalam Surat Keputusan Direksi Bank Indonesia No. 31/82/KEP/DIR tentang Persyaratan dan Tata Cara Pemberian Ijin atau Perintah Membuka Rahasia Bank tanggal 31 Desember $1988 .{ }^{25}$

Dalam pasal 1 butir 6 disebutkan, Rahasia Bank adalah segala sesuatu yang berhubungan dengan keterangan mengenai nasabah penyimpan dan

${ }^{24}$ Surat Keputusan Direksi Bank Indonesia Nomor 27/120/KEP/DIR tentang Tata Cara Tukar Menukarkan Informasi Antar Bank, 25 Januari 1995

${ }^{25}$ Sentosa Sembiring, Hukum Perbankan, (Bandung: Mandar Maju, 2000), h. 39 
simpanannya. Selanjutnya dalam pasal 2 disebutkan:

Pertama, Bank wajib merahasiakan keterangan mengenai nasabah penyimpan dan simpanannya;

Kedua, Ketentuan sebagaimana dimaksud dalam ayat 1 tidak bertaku untuk: a. Kepentingan perpajakan; b. Penyelesaian piutang bank yang sudah diserahkan kepada Badan Urusan Piutang Negara dan Lelang Negara (BUPLN)/Panitia Urusan Piutang Negara (PUPN); c. Kepentingan peradilan dalam perkara pidana; d. Kepentingan peradilan dalam perkara perdata antara bank dengan nasabahnya; e. Tukar-menukar informasi antar bank; $f$. Permintaan, persetujuan atau kuasa nasabah penyimpan yang dibuat secara tertulis; g. Permintaan ahli waris yang sah dari nasabah penyimpan yang telah meninggal dunia. ${ }^{26}$

Ketentuan rahasia bank sebagaimana di atas, merupakan kewajiban bank. Berhubung hal tersebut merupakan kewajiban, maka pelanggarannya dapat dikenakan sejumlah sanksi. Dalam Undang-Undang Perbankan 1998 dikenal dua macam sanksi, yaitu sanksi pidana dan sanksi administratif.

Ketentuan rahasia bank wajib dipegang teguh oleh bank, karena tujuannya untuk melindungi kepentingan bank dan nasabahnya. Meskipun demikian peraturan tersebut masih terdapat kelemahannya, manakala bank terdapat persoalan yang tidak beres, seperti terjadinya kredit macet dalam jumlah besar. Kelemahan aturan rahasia bank dapat menghambat hubungan antara DPR dengan pemerintah (dalam hal ini bank). Di Satu pihak DPR tidak dapat melakukan pengawasan, sedangkan di lain pihak berlindung di balik rahasia bank dengan berdiam diri kalau didiamkan saja keadaan bank akan semakin bertambah kurang baik.

Dengan demikian untuk mengatasi masalah tersebut di atas, maka rahasia bank perlu ditambah kekecualiannya, khususnya untuk kepentingan ketatanegaraan. Bank dapat memberikan keterangan keadaan keuangan nasabah kepada DPR jika terjadi keadaan yang membahayakan bank maupun sistem perbankan pada umumnya.

\section{Penutup}

Pada dasarnya, rahasia bank bersifat mutlak, yaitu bank memiliki kewajiban menyimpan rahasia nasabah yang diketahui oleh bank karena kegiatan usahanya dalam keadaan apapun, biasa atau dalam keadaan luar biasa. Walau pun disisi lain bersifat nisbi, artinya bank diperbolehkan membuka rahasia nasabahnya, bila untuk suatu kepentingan mendesak, misalnya demi kepentingan negara. Oleh karenanya, ada mekanisme dan prosedur serta ketentuan pembukaan rahasia bank, seperti untuk kepentingan perpajakan, untuk kepentingan penyelesaian piutang negara, untuk kepentingan peradilan pidana, untuk kepentingan peradilan dalam perkara perdata, dan untuk kepentingan kegiatan perbankan. Dengan demikian ketentuan baku penjaminan kerahasiaan bank tidak lagi bersifat mutlak, tetapi bersifat nisbi. 
Bergantung kepada kepentingan negara dan orang banyak, bukan kepentingan individual semata.

\section{Pustaka Acuan}

Abdurrachman, A., Ensiklopedia Ekonomi Keuangan dan Perbanakan, dalam Thomas Suyamo, et al., Kelembagaan Perbankan.

Andreae, Fockema, "Kamus 1stilah Hukum", dalam. H. Budi Untung, Kredit Perbankan di Indonesia, Yogjakarta: Andi Yogjakarta, 2000.

Anwari, Achmad, Rekening Koran Giro, Jakarta: Balai Aksara, 1991.

Djumhana, Muhammad, Hukum Perbankan di Indonesia, Bandung: PT. Citra Aditya Bakti, 2000.

Hasibuan, Malayu SP., Dasar-Dasar Perbankan, Jakarta: Bumi Aksara, 2001.

Sembiring, Sentosa, Hukum Perbankan, (Bandung: Mandar Maju, 2000), h. 39

Simorangkir, O.P., Seluk Beluk Bank Komersial, Cetakan I, Jakarta: Perbanas, 1998.

Sinungan, Muchdarsyah, Manajemen Dana Bank, Jakarta: Bumi Aksara, 2000.

Stuart, G.M. Verryn, "Bank Politik", dalam Thomas Suyatno. et. al., Kelembagaan Perbankan, Jakarta: Gramedia, 1992.

Sunggono, Bambang, Pengantar Hukum Perbankan, Bandung: Mandar Maju, 1995.

Surat Keputusan Direksi Bank Indonesia Nomor 27/120/KEP/DIR tentang Tata Cara Tukar Menukarkan Informasi Antar Bank, 25 Januari 1995

Susilo, Y. Sri, dan Sigit Triandaru, Bank \& Lembaga Keuangan Lain, Jakarta: Salemba Empat, 2000.

Undang-Undang No. 10 Tahun 1998, tentang Perbankan 